\title{
GIARDIA LAMBLIA
}

\section{THE INCIDENCE AND RESULTS OF INFESTATION OF CHILDREN IN RESIDENTIAL NURSERIES}

\author{
BY \\ E. H. BROWN, B.M., D.C.H.
}

Introduction

Numerous factors exert an adverse influence on the health of children in residential nurseries, of which diarrhoea in its various forms remains the most serious and one of the most insoluble. Apart from the occasional outbreaks of epidemic gastroenteritis and Sonne dysentery, there is a high incidence of loose stools, and amongst the children who have been at a nursery several months this may take the form of a chronic intermittent diarrhoea. The purpose of this paper is to describe an investigation into the degree of infestation of nursery children with the flagellate protozoon, Giardia lamblia, and to assess its influence not merely in the production of diarrhoea, but on the level of health of the children as shown by failure to gain weight, and by anaemia, poor appetite, etc.

Before the discovery that mepacrine was a specific treatment for Giardiasis (Galli Valerio, 1937), opinions differed widely on the pathogenicity of the organism. Miller (1926) came to the conclusion that Giardiasis was a cause of chronic enteritis in children, but Boeck (1927) gives a rather unconvincing account in support of his belief that Giardia is not pathogenic. Véghelyi (1938, 1940), who has been responsible for much of the later work, considers the three characteristic signs of Giardiasis to be abdominal complaints, anaemia, and retarded development. Steatorrhoea attributable to Giardiasis has been described by Véghelyi (1940), and by McGrath and others (1940). Ormiston and others (1942) reported enteritis associated with Giardiasis in a nursery; and Sudds (1943) reported an outbreak in a nursery school. In both these outbreaks, following treatment with mepacrine, Giardia cysts disappeared from the stools, the diarrhoea ceased, and an improvement was noted in the health of the children.

\section{The Ladywell Nursery}

The nursery at which this investigation was carried out is one of the largest and most modern residential nurseries in London. It consists of four separate blocks, and it was intended that each block should be a self-contained unit, except that the food is supplied from a central kitchen. There is accommodation for 156 children up to three years

TABLE 1

ALLOCATION OF ACCOMMODATION: LADYWELL NURSERY

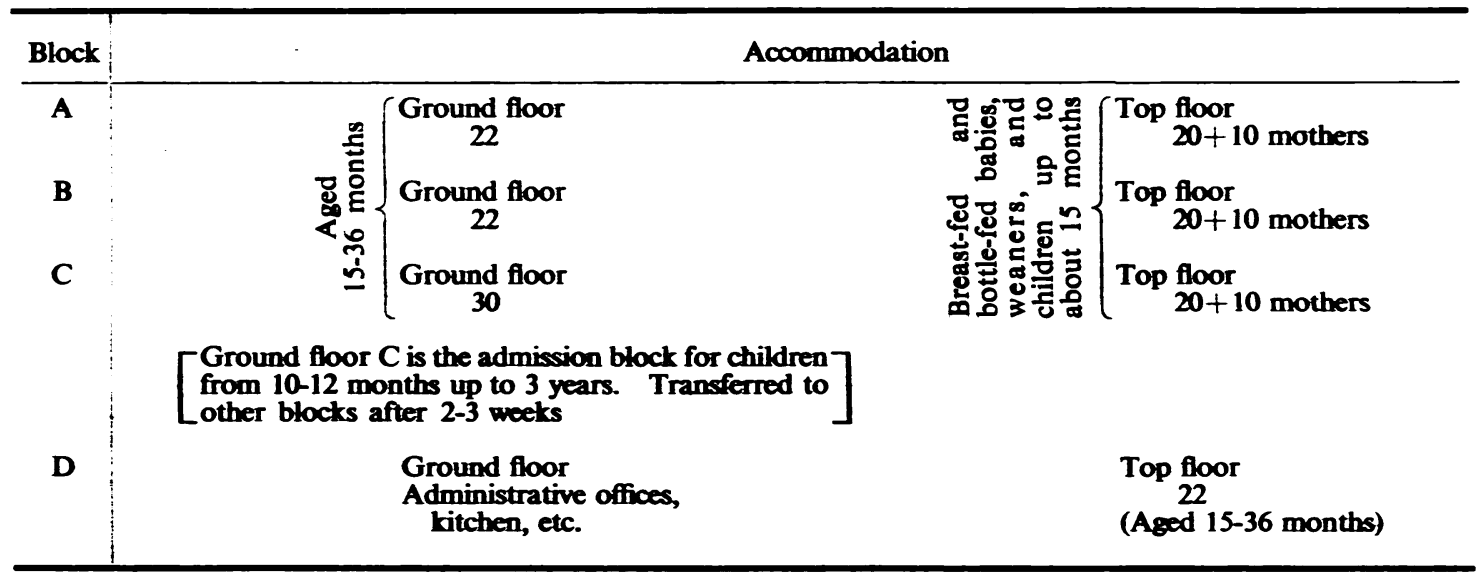


of age and thirty mothers, the allocation of the children being as shown in table 1 .

On leaving the admission block ' $C$ ' the children over one year are transferred to ' $D$.' On the ground floors of ' $A$ ' and ' $B$ ' are the long-stay children, aged about fifteen to thirty-six months, that is, those whose stay at the nursery is three months or more, and they are recruited from ' $D$ ' when it becomes evident which children are destined to stay long.

Ether concentration method of examination for Giardia bamblia. Direct examination of the stools for Giardia cysts is an unreliable method, and unless repeated examinations are made a large number of cases will be missed. It was therefore decided to use the ether concentration method.

An amount of faeces equal to the size of a large pea is emulsified with normal saline in a $1 \mathrm{oz}$. screw-cap bottle. A layer of ether is added and the bottle thoroughly shaken. Most of the unwanted debris is taken up in the ether layer. The lower layer of saline containing the cysts and ova is pipetted into a centrifuge tube and spun at 1,500/ min. for between five and seven minutes. The supernatant fluid is then discarded and a loopful of the deposit placed on a slide and stained with Gram's iodine; a coverslip is applied.

\section{Details of the Observations}

Incidence of infestation with Giandia lamblia. An initial survey involving the examination of one stool from every child in the nursery yielded no positive stools in children under one year. Although a few cases were subsequently found, it was decided that further study of this group was unlikely to yield sufficient information for any conclusive results. All the results given below therefore refer to children aged from one to three years.

INCIDENCE ON ADMISSION TO THE NURSERY. Stools were examined from 139 consecutive admissions over one year of age, two specimens from each child being examined where possible during the

TABLE 2

GIARDIA INFESTATION AND PREVIOUS HISTORY OF NURSERY LIFE

\begin{tabular}{|c|c|c|c|c|}
\hline \multirow{2}{*}{\multicolumn{2}{|c|}{ History }} & \multirow{2}{*}{$\begin{array}{l}\text { No. of child- } \\
\text { ren examined } \\
\text { on admission }\end{array}$} & \multicolumn{2}{|c|}{ Found to be positive } \\
\hline & & & No. & ${ }_{0}^{\circ}$ \\
\hline (a) & $\begin{array}{l}\text { Previously at- } \\
\text { tended day or } \\
\text { residential } \\
\text { nursery }\end{array}$ & 30 & 15 & $50 \cdot 0$ \\
\hline (b) & $\begin{array}{l}\text { No previous } \\
\text { history of } \\
\text { nursery at- } \\
\text { tendance }\end{array}$ & 56 & 8 & $14 \cdot 3$ \\
\hline
\end{tabular}

first week at the nursery. Thirty-seven out of 139 children (26.6 per cent.) had Giardia cysts in their stools. The difference between the incidence at one to two, and two to three years was not significant $\left(P_{\chi^{2}}=0 \cdot 60\right)$.

The parents were asked whether their children had previously attended a day or residential nursery before their admission to Ladywell Nursery and information was obtained in eighty-six cases (table 2). The difference between the two groups of children ( $a$ and $b$ ) is significant $\left(P_{\chi^{2}}<0.001\right)$. This merely shows that Giardia is more frequently present in children with a history of previous nursery attendance, and it does not prove direct association with nursery life. It is probable, however, that amongst London children in the age group one to three years the incidence of Giardia infestation is somewhat lower than in the 139 children admitted to this nursery.

INCIDENCE IN LONG-STAY CHILDREN. By long Stay is meant those children who have been at the nursery three months or more, and since in this nursery the great majority of children on the ground floors of ' $A$ ' and ' $B$ ' blocks stay this long the incidence of Giardia infestation here may be taken as the incidence in long-stay children. The examinations were carried out during January, 1947. In 'A ' block, out of nineteen children, fifteen had Giardia cysts in their stools. In ' $B$ ' block, out of twenty children, sixteen had Giardia cysts in their stools (table 3). The low incidence in the age group twelve to eighteen months may be explained by the fact that these children had not long been transferred from the top floors, where the incidence amongst the children up to fifteen months is low. In the case of two of the negative children on ' $A$ ' block, one had been positive at the initial survey, and the other positive at a subsequent date. One of the four negative children on ' $B$ ' block was later found to be positive. It appears, therefore, that the majority of long-stay children in this nursery are infested with Giardia. Spread of infection probably occurs from child to child by finger and faecal ingestion of cysts, though contaminated dust may be of importance.

\section{TABLE 3}

INCIDENCE OF GIARDIA INFESTATION IN A AND B BLOCKS ACCORDING TO AGE

\begin{tabular}{|c|c|c|c|}
\hline \multirow{2}{*}{ Age (months) } & \multirow{2}{*}{$\begin{array}{l}\text { Number of } \\
\text { children }\end{array}$} & \multicolumn{2}{|c|}{ Found to be positive } \\
\hline & & No. & $o_{0}$ \\
\hline $\begin{array}{l}12-18 \\
18-24 \\
24-30 \\
30-36\end{array}$ & $\begin{array}{r}7 \\
15 \\
8 \\
9\end{array}$ & $\begin{array}{r}2 \\
13 \\
7 \\
9\end{array}$ & $\begin{array}{r}29 \\
87 \\
88 \\
100\end{array}$ \\
\hline Total & 39 & 31 & 79 \\
\hline Over 18 months & 32 & 29 & 91 \\
\hline
\end{tabular}


INCIDENCE AT OTHER RESIDENTIAL NURSERIES.

(a). St. Margaret's Nursery. The great majority at this nursery are destined to be long-stay children, and the rate of admission is consequently low in comparison with Ladywell Nursery. There is accommodation for about eighty children up to three years. Stools were examined from fifty children more than one year old, and in most cases two specimens were examined from each child. Twenty-three out of fifty children (46 per cent.) had Giardia cysts in their stools.

The lower incidence in this nursery may be explained by the fact that there was a larger proportion in the age group twelve to eighteen months (the incidence over eighteen months was 70 per cent.), and by the difference in the type of accommodation. In this nursery the children are segregated into small groups, and as it was formerly an infectious diseases hospital the accommodation is peculiarly suited to this purpose, and there is thus less opportunity for cross infection.

(b.) South-Eastern Hospital Nursery. This consists of two large wards in what was formerly a fever hospital, and each ward holds about twenty-one children. Out of thirteen children over one year of age in one of these wards, eight had Giardia cysts in their stools (61-5 per cent.). Excluding two children who had been at the nursery less than three months, the incidence was $72 \cdot 7$ per cent.

It is evident therefore that the high incidence is not peculiar to Ladywell Nursery and that the majority of long-stay children above one year of age in residential nurseries are infested with Giardia lamblia.

RATE OF INFESTATION WITH GIARDIA AFTER ADMISSION TO THE NURSERY. Stool examination was carried out at monthly intervals during the child's stay at the nursery. It is evident from table 4 that a rapid rate of infestation occurs.

TABLE 4

RATE OF INFESTATION WITH GIARDIA AFTER ADMISSION TO THE NURSERY

\begin{tabular}{|c|c|c|c|c|c|}
\hline \multirow{2}{*}{$\begin{array}{c}\text { Period } \\
\text { after } \\
\text { admission } \\
\text { (months) }\end{array}$} & \multirow{2}{*}{$\begin{array}{l}\frac{2}{2} \\
\frac{0}{2} \\
\frac{g}{E}\end{array}$} & \multirow{2}{*}{$\begin{array}{l}\text { Number of } \\
\text { children } \\
\text { negative } \\
\text { at previous } \\
\text { examinations }\end{array}$} & \multicolumn{2}{|c|}{$\begin{array}{l}\text { Found to } \\
\text { be positive }\end{array}$} & \multirow{2}{*}{ 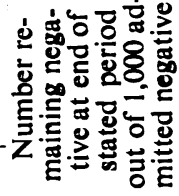 } \\
\hline & & & No. & $\%$ & \\
\hline $\begin{array}{l}0 \\
1 \\
2\end{array}$ & 139 & $\begin{array}{l} \\
* 56 \\
* 15\end{array}$ & \begin{tabular}{r|r|r}
37 & \\
11 & 8 \\
8
\end{tabular} & $\begin{array}{l}26 \cdot 6 \\
19 \cdot 6 \\
53 \cdot 3\end{array}$ & $\begin{array}{r}1,000 \\
804 \\
375\end{array}$ \\
\hline
\end{tabular}

* These are the number of children out of the 139 admissions who were still present in the nursery one and two months respectively after admission. If those positive at one month and again at two months are included, eleven out of eighteen (61-1 per cent.) who were negative on admission were infested at two months.

INCIDENCE IN ADULTS. Stools were examined from the nurses, mothers, and kitchen staff at the nursery. One specimen only was examined in each case. Some difficulty was experienced in getting specimens from the adults, but the figures include all the kitchen staff and about 75 per cent. of the nurses and mothers (table 5). There is clearly no significant difference between the various adult groups, but the overall incidence in adults is significantly lighter than in nursery children. $\mathbf{P X}^{2}=<0 \cdot 00001$.

\section{TABLE 5}

INCIDENCE OF GIARDIA IN ADULTS

\begin{tabular}{|c|c|c|c|}
\hline \multirow{2}{*}{ Group } & \multirow{2}{*}{$\begin{array}{l}\text { Number of } \\
\text { adults }\end{array}$} & \multicolumn{2}{|c|}{ Found to be positive } \\
\hline & & No. & $\%$ \\
\hline $\begin{array}{l}\text { Nurses } \\
\text { Kitchen staff } \\
\text { Mothers } \quad \text {. }\end{array}$ & $\begin{array}{r}48 \\
9 \\
25\end{array}$ & $\frac{2}{1}$ & $\frac{4 \cdot 2}{4 \cdot 0}$ \\
\hline Total & 82 & 3 & $3 \cdot 7$ \\
\hline
\end{tabular}

Character of stools and rebationship to Giardia infestation. When the specimens of faeces were examined for Giardia cysts a note was made also of their consistency. The following classification was used:

(1) formed stool 1$\}$ Classed as normal

(3) relaxed stool (which included the intermediate forms between (2) and (3))

(4) fluid stool

It was not possible from the small specimens received to give any satisfactory quantitative estimate for such details as completeness of digestion, presence of mucus, etc.

CHARACTER OF STOOLS OF CHILDREN ON ADMISSION TO THE NURSERY. It was decided to include only those children from whom two specimens had been obtained and from these to take the first specimen only, excluding those from whom the first specimen had been obtained more than seven days after admission. By this means a more accurate picture was obtained of the type of stool on admission to the nursery. Table 6 clearly shows that on admission to the nursery there is no significant stool difference between children with Giardia cysts and those without.

Character of STOOLS AND RELATION TO LENGTH OF STAY IN NURSERY. The same procedure was carried out for the stool examinations one month (or more) after admission, and also for the various stool examinations of the children who had been in the nursery for three months or more. The great majority of the latter children were infested with Giardia. It was not considered satisfactory to subdivide the former into Giardia-positive and Giardia-negative because infestation with Giardia might already have occurred although cysts were not yet present in the stools, and it was also difficult to evaluate what other factors were present predisposing to loose stools. 
TABLE 6

CHARACTER OF STOOLS ON ADMISSION TO THE NURSERY

(Specimens obtained within seven days of admission)

\begin{tabular}{|c|c|c|c|c|c|c|c|c|c|}
\hline \multirow{4}{*}{\multicolumn{3}{|c|}{$\begin{array}{l}\text { Whether child positive } \\
\text { or negative on } \\
\text { admission }\end{array}$}} & \multirow{4}{*}{\begin{tabular}{|c} 
\\
Total \\
specimens \\
examined
\end{tabular}} & \multicolumn{3}{|r|}{ - } & \multicolumn{3}{|c|}{ Stool } \\
\hline & & & & \multicolumn{3}{|c|}{ Normal } & \multicolumn{3}{|c|}{ Relaxed or fluid } \\
\hline & & & & \multicolumn{2}{|c|}{ No. } & \multirow[t]{2}{*}{$\%$} & \multicolumn{2}{|c|}{ No. } & \multirow[t]{2}{*}{$\%$} \\
\hline & & & & (1) & (2) & & (3) & (4) & \\
\hline $\begin{array}{l}\text { (a) Positive } \\
\text { (b) Negative }\end{array}$ & $\begin{array}{l}\cdots \\
\cdots\end{array}$ & $\cdots$ & $\begin{array}{l}29 \\
81\end{array}$ & $\begin{array}{l}18 \\
53\end{array}$ & $\begin{array}{r}8 \\
22\end{array}$ & $\begin{array}{l}89 \cdot 7 \\
92 \cdot 6\end{array}$ & $\begin{array}{l}3 \\
6\end{array}$ & - & $\begin{array}{r}10 \cdot 3 \\
7 \cdot 4\end{array}$ \\
\hline Total (a) $-(b)$ & . & $\cdots$ & 110 & 71 & 30 & $91 \cdot 8$ & 9 & - & $8 \cdot 2$ \\
\hline
\end{tabular}

TABLE 7

CHARACTER OF STOOLS AND RELATION TO LENGTH OF STAY IN NURSERY

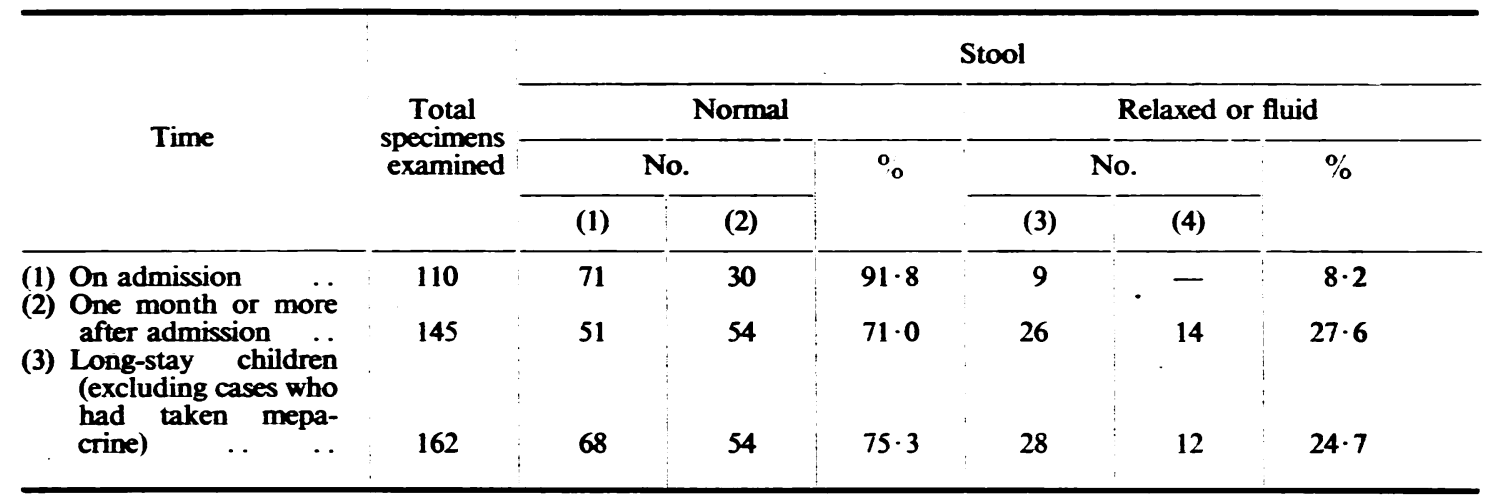

The differences between (1) and (2) and between (1) and (3) in table 7 are significant. $P_{\chi}{ }^{2}=<0 \cdot 001$ in both instances.

Loose stools are more frequent in these nursery children. The type of stool passed by children after a long stay in the nursery is more strikingly different than is suggested by the above figures, and interestingly aperients in residential nurseries of this type are rarely required. On admission a brown, well-formed stool is usual; but this emphatically is not the case in the long-stay child, with whom the average stool tends to be rather grey in colour, and of greasy appearance, although its consistency may be within normal limits. The undigested stool is also, common, and excess mucus may be noticeable in some of these.

The relationship of height, weight, haemoglobin percentage, and faecal fats to Giardia infestation.

WEIGHT AND HEIGHT OF NURSERY CHIIDREN AND RELATIONSHIP TO GIARDIA INFESTATION. SOme difficulty was experienced in obtaining a suitable standard for heights and weights of children between one and three years. No standard was available for nursery children or even for children of this age group in the London area, so the one finally used was an accepted American standard compiled from the University of Iowa Studies in Child Welfare (Meredith, H. V., 1935, and Boynton, B., 1936, and quoted in Mitchell-Nelson's 'Textbook of Paediatrics ').

As this is a standard for American children it was decided that the weights and heights of a group of healthy British children should be obtained for comparison, before applying the standard to the nursery children. For this purpose the heights and weights of children of this age group (one to three years) attending a local infant welfare clinic were obtained, and the results were as shown in table 8.

The weights of these children attending the infant welfare clinic compare favourably with the standard, but it seems that the standard for heights is rather high for the average London child of this age group.

(a.) Weights and heights on admission to the nursery. The children were divided into those who had Giardia cysts in their stools on admission and those who had not (table 9).

The differences between the actual and expected mean height and weight of those children who were Giardia infested on admission are somewhat greater 
than that of the children who were Giardia-negative on admission, but the differences between the two groups for both heights and weights are not statistically significant. As was mentioned previously, a greater proportion of Giardia-positive children had previously attended a nursery, and this may be a factor accounting for the small differences between the two groups.

(b.) Weights and heights in long-stay children. The weights of fifty-two children and the heights of forty children who had lived in the nursery for three months or more were obtained. It was desirable to know whether these children who were destined to stay long were inferior to the average admission child. Thirty-six long-stay children who were over one year of age on admission to the nursery were taken, and their weights on admission and later were recorded in table 10 . The expected heights and weights are the mean of individual expectations according to the standard used.

The conclusions to be drawn from table 10 are:

1. The longer a child remains at this nursery the more subnormal he becomes.

2. The average child on admission to the nursery is inferior both in height and weight to an average child attending a local infant welfare centre. This is to be expected because the conditions necessitating admission to a residential nursery are often similar to those having an adverse influence on the physical health of a child.

3. A child, after admission to a large residential nursery, does not show an improvement as might be expected, but becomes gradually more subnormal.

TABLE 8

HEIGHT AND WEIGHT OF CHILDREN AGED ONE TO THREE YEARS ATTENDING AN INFANT WELFARE CLINIC

\begin{tabular}{|c|c|c|c|c|c|c|c|}
\hline \multirow{2}{*}{ Number weighed } & \multicolumn{3}{|c|}{ Mean weight (lb.) } & \multirow{2}{*}{$\begin{array}{l}\text { Number } \\
\text { measured }\end{array}$} & \multicolumn{3}{|c|}{ Mean height (in.) } \\
\hline & Actual & Expected ${ }^{*}$ & Difference & & Actual & Expected $*$ & Difference \\
\hline 88 & $29 \cdot 17$ & $29 \cdot 08 \pm 0 \cdot 32$ & +0.09 & 30 & $34 \cdot 12$ & $\overline{34 \cdot 99 \pm 0 \cdot 22}$ & -0.87 \\
\hline
\end{tabular}

- Expected = means of individual expectations according to the standard.

TABLE 9

WEIGHT AND HEIGHT ON ADMISSION AND RELATIONSHIP TO GIARDIA INFESTATION

\begin{tabular}{|c|c|c|c|c|c|c|c|c|}
\hline \multirow{2}{*}{$\begin{array}{l}\text { Giardia cysts } \\
\text { on admission }\end{array}$} & \multirow{2}{*}{$\begin{array}{l}\text { Number } \\
\text { weighed }\end{array}$} & \multicolumn{3}{|c|}{ Mean weight (lb.) } & \multirow{2}{*}{$\begin{array}{l}\text { Number } \\
\text { measured }\end{array}$} & \multicolumn{3}{|c|}{ Mean height (in.) } \\
\hline & & Actual & Expected* & Difference & & Actual & Expected* & Difference \\
\hline $\begin{array}{l}\text { Present } \\
\text { Absent }\end{array}$ & $\begin{array}{l}37 \\
99\end{array}$ & $\begin{array}{l}24 \cdot 67 \\
25 \cdot 30\end{array}$ & $\begin{array}{l}27 \cdot 20 \div 0 \cdot 48 \\
27 \cdot 11 \pm 0 \cdot 29\end{array}$ & $\begin{array}{l}-2 \cdot 53 \\
-1 \cdot 91\end{array}$ & $\begin{array}{l}34 \\
81\end{array}$ & $\begin{array}{l}31 \cdot 69 \\
32 \cdot 01\end{array}$ & $\begin{array}{l}33 \cdot 64 \pm 0 \cdot 20 \\
33 \cdot 62 \pm 0 \cdot 13\end{array}$ & $\begin{array}{r}-1.95 \\
-1.61\end{array}$ \\
\hline
\end{tabular}

* The expected beights and weights are the means of individual expectations on the standard used.

TABLE 10

HEIGHTS AND WEIGHTS OF CHILDREN ON ADMISSION TO THE NURSERY AND AFTER THREE MONTHS OR MORE

\begin{tabular}{|c|c|c|c|c|c|c|c|c|}
\hline \multirow{2}{*}{ Group } & \multirow{2}{*}{$\begin{array}{l}\text { Number } \\
\text { weighed }\end{array}$} & \multicolumn{3}{|c|}{ Mean weight (lb.) } & \multirow{2}{*}{$\begin{array}{l}\text { Number } \\
\text { measured }\end{array}$} & \multicolumn{3}{|c|}{ Mean height (in.) } \\
\hline & & Actual & Expected & Difference & & Actual & Expected & Difference \\
\hline $\begin{array}{l}\text { On admission } \\
\text { (from table 9) } \\
\text { Long-stay children } \\
\text { Long-stay children } \\
\text { over 1 year on } \\
\text { admission: } \\
\text { (a) on admission } \\
\text { (b) after } 3 \\
\text { months or } \\
\text { more }\end{array}$ & $\begin{array}{l}36 \\
36\end{array}$ & $\begin{array}{l}24 \cdot 73 \\
27 \cdot 06\end{array}$ & $\begin{array}{l}27 \cdot 13 \pm 0.25 \\
28 \cdot 64 \pm 0.42 \\
26 \cdot 97 \pm 0.48 \\
29 \cdot 72 \pm 0.52\end{array}$ & $\begin{array}{l}-2 \cdot 24 \\
-2 \cdot 66\end{array}$ & $\begin{array}{r}115 \\
40\end{array}$ & $\begin{array}{l}31 \cdot 92 \\
31 \cdot 37\end{array}$ & $\begin{array}{l}33 \cdot 63=0 \cdot 11 \\
34 \cdot 56 \div 0 \cdot 19\end{array}$ & $\begin{array}{c}-1 \cdot 71 \\
-3 \cdot 19 \\
.\end{array}$ \\
\hline
\end{tabular}


HAFMoglobin OF. ADMISSION AND LONG-STAY CHILDREN. This was determined by the Haldane method, using for comparison a B.S. tube No. 1079 (table 11). Age for age there is no significant difference between the two groups. Of ten admission cases with haemoglobin less than 70 per cent., three were positive for Giardia, and of four long-stay cases with haemoglobin less than 70 per cent., three were positive for Giardia. In neither case is this significantly different from expectation for all admissions or long-stay children respectively, regardless of haemoglobin.

TABLE 11

HAEMOGLOBIN OF ADMISSION AND LONGSTAY CHILDREN

\begin{tabular}{|c|c|c|c|c|c|}
\hline \multirow{2}{*}{ Group } & \multirow{2}{*}{$\begin{array}{c}\text { Age } \\
\text { (months) }\end{array}$} & \multicolumn{4}{|c|}{ Haemoglobin } \\
\hline & & $<70 \%$ & $70-80 \%$ & $\begin{array}{c}80 \% \text { and } \\
\text { over }\end{array}$ & $\begin{array}{c}\text { Total } \\
\text { no. of } \\
\text { children }\end{array}$ \\
\hline \multirow[t]{2}{*}{$\begin{array}{c}\text { On ad- } \\
\text { mission }\end{array}$} & $\begin{array}{l}12-18 \\
18-24 \\
24-30 \\
30-36\end{array}$ & $\begin{array}{l}3 \\
3 \\
3 \\
1\end{array}$ & $\begin{array}{r}17 \\
14 \\
4 \\
5\end{array}$ & $\begin{array}{r}14 \\
17 \\
14 \\
5\end{array}$ & $\begin{array}{l}34 \\
34 \\
21 \\
11\end{array}$ \\
\hline & Total & 10 & 40 & 50 & 100 \\
\hline \multirow[t]{2}{*}{$\begin{array}{l}\text { Long- } \\
\text { stay }\end{array}$} & $\begin{array}{l}12-18 \\
18-24 \\
24-30 \\
30-36\end{array}$ & $\frac{\overline{4}}{1}$ & $\begin{array}{l}1 \\
6 \\
2 \\
4\end{array}$ & $\begin{array}{l}4 \\
7 \\
5 \\
8\end{array}$ & $\begin{array}{r}5 \\
17 \\
7 \\
13\end{array}$ \\
\hline & Total & 5 & 13 & 24 & 42 \\
\hline
\end{tabular}

THE FAECAL FATS OF A GROUP OF LONG-STAY CHILDREN. Steatorrhoea has been described as occurring in cases of heavy infestation with Giardia lamblia (Véghelyi, 1940). The greyish, rather greasy stools which are so commonly found in residential nurseries suggested that a high fat content in them might be expected. A group of fourteen was selected from the long-stay children, Giardia infestation having been found in thirteen of them. All these children were below expected weight according to the standard, muscle tone was poor, and they had a history of loose stools at some time during their stay in the nursery, and many of them a history of intermittent diarrhoea. The clinical picture presented by these children resembled quite well that which has been described as due to Giardia infestation. In all cases the faecal fats were within normal limits, although two cases were a little high (total fat $34 \cdot 4$ and $37 \cdot 6$ per cent. respectively). The mean of the fourteen cases was total fat per cent. $25 \cdot 35 \pm 1 \cdot 89$, split fat $22 \cdot 51 \pm 1 \cdot 80$, unsplit fat $2 \cdot 84 \pm 0 \cdot 30$.

The food intake of these children was also measured. From the nutritional aspects the intakes appeared to be ample, and the total fat per twentyfour hours tended perhaps to be rather on the high side of the optimum. It did not appear, therefore, that steatorrhoea was a manifestation of Giardia infestation in this nursery.

The effects of treatment with mepacrine.

MEPACRINE TREATMENT - EFFECT ON GROWTH. As previously mentioned, the great majority of the children on the ground floors of ' $A$ ' and ' $B$ ' blocks were long-stay children between the age of fifteen months and three years with a very high incidence of Giardia infestation. They were therefore eminently suitable for a study of the effect of Giardia infestation and results of treatment (table 12). Regarding the absolute physique of the two groups, that part of the difference which is not accounted for by age is well within the range of sampling error, and the two groups may be regarded as comparable.

TABLE 12

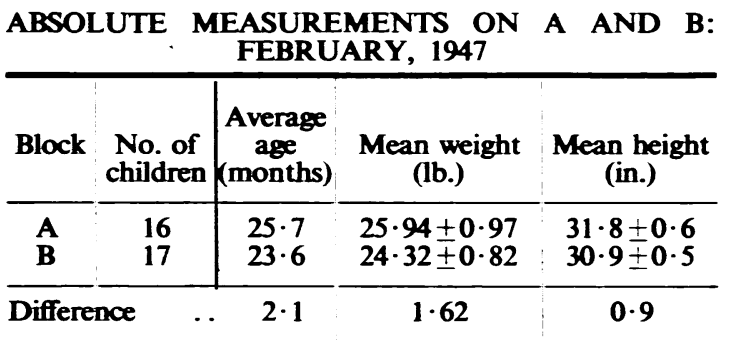

\begin{tabular}{lllll}
\hline $\begin{array}{l}\text { Expected difference on } \\
\text { basis of age }\end{array} \quad \ldots$ & 0.86 & 0.7 \\
\hline $\begin{array}{l}\text { Difference not explained } \\
\text { by age } \\
\text { b }\end{array}$ & 0.76 & 0.2
\end{tabular}

It was decided to treat the children on ' $B$ ' block with mepacrine and to use those on ' $A$ ' block as controls. Mepacrine treatment was started on ' $B$ ' in the middle of February and all the children in this group received it. The mepacrine was given in the form of $0.025 \mathrm{~g}$. tablets, and children under eighteen months were given $0.075 \mathrm{~g}$. daily and those over eighteen months $0.1 \mathrm{~g}$. daily, the course lasting five days. No toxic symptoms were observed, although a few children developed a yellow colour of the skin, but in no case was this marked.

Examination of the stools a few days after treatment showed that there was complete elimination of Giardia cysts from the stools. Stools from all the children treated with mepacrine were subsequently examined at monthly intervals until the end of June, and in no case were any Giardia cysts demonstrated during the period of survey. All children subsequently admitted to this block received a course of mepacrine before mixing with the other children. Mepacrine thus provides a simple and reliable method for the elimination of Giardia infestation.

A record had previously been obtained of the gain in weight per week of long-stay children on 
' $A$ ' and ' $B$ ' blocks during the period October, 1946, to February, 1947; comparably the mean gain in weight and height on ' $A$ ' and ' $B$ ' during the period of survey were obtained, and are shown in table 13. There is no significant difference between the rates of weight gain of the children in the two blocks before treatment, and there is no significant difference between the rates of weight gain of the control group in the two periods. The rate of gain of the mepacrine group during the period after treatment is significantly higher than before treatment and higher than that of the control group. The difference in height gain between the controls and the treated group is $0.024 \pm 0.014$, which is barely significant.

TABLE 13

GROWTH-COMPARISON BETWEEN CHILDREN .ON A AND B BLOCKS BEFORE AND AFTER MEPACRINE

\begin{tabular}{|c|c|c|c|c|}
\hline \multirow{2}{*}{ Period } & \multirow{2}{*}{ Group } & \multirow{2}{*}{$\begin{array}{l}\text { No. of } \\
\text { children }\end{array}$} & \multicolumn{2}{|c|}{ Mean gain per week } \\
\hline & & & Weight (oz.) & Height (in.) \\
\hline $\begin{array}{l}\text { Oct., } \\
1946 \text { to } \\
\text { Feb. } \\
1947\end{array}$ & $\begin{array}{l}\mathbf{A} \\
\mathbf{B}\end{array}$ & $\begin{array}{l}21 \\
21\end{array}$ & $\begin{array}{l}1 \cdot 52=0 \cdot 28 \\
1 \cdot 16=0 \cdot 21\end{array}$ & \\
\hline $\begin{array}{l}\text { Feb. } \\
1947 \text { to } \\
\text { June, } \\
1947\end{array}$ & $\begin{array}{c}\text { A } \\
\text { (con- } \\
\text { trols) } \\
\text { B } \\
\text { (mepa- } \\
\text { crine) }\end{array}$ & $\begin{array}{l}21 \\
21\end{array}$ & $\begin{array}{l}1 \cdot 54=0 \cdot 24 \\
2 \cdot 79 \leq 0 \cdot 22\end{array}$ & $\begin{array}{l}0.079=0.009 \\
0.103=0.010\end{array}$ \\
\hline
\end{tabular}

During the period of survey, bacteriological examination of the stools from ' $A$ ' and ' $B$ ' blocks did not reveal any pathogenic organisms. There was an outbreak of whooping-cough on ' $B$ ', block at the end of February and during March. Five cases occurred during this period, and there were one or two suspicious cases which were not confirmed. It is possible that, but for this unfortunate occurrence, the difference between ' $A$ ' and ' $B$ ' would have been even more marked. There were no other serious diseases on these blocks during this period.

LOOSE STOOLS ON ' A' AND ' B' BEFORE AND AFTER MEPACRINE. For this purpose a record was made of the number of days on which a child was reported by the sister-in-charge as having loose stools. The information is necessarily incomplete, because owing to the frequent occurrence of loose stools in this nursery the first loose stool may not be reported and subsequently may not be mentioned throughout the period of the diarrhoea. An attempt was made to obtain a complete record of the number of stools passed per day by each child on these two blocks, but this proved impossible. The former method was applied for the period from the beginning of mepacrine treatment on ' $B$, block in February until the end of May, and also for a similar period on ' $A$ ' and ' $B$ ' blocks (three and a half months) prior to the use of mepacrine.

No dramatic results were observed during the first week or two after the use of mepacrine on ' $B$, block. This accords with the view of Véghelyi (1940), who considered that recovery took from three and a half to seven weeks after treatment. But during the subsequent months it was unquestionably evident that the incidence of loose stools on the treated block was less than on the control block (table 14).

TABLE 14

LOOSE STOOLS AND/OR VOMITING REPORTED ON A AND B BLOCKS

\begin{tabular}{ccccc:c}
\hline & \multicolumn{2}{c}{ A Block } & \multicolumn{2}{c}{ B Block } \\
\cline { 2 - 5 } Period & $\begin{array}{c}\text { Total } \\
\text { reports* }\end{array}$ & $\begin{array}{c}\text { No. of } \\
\text { children } \\
\text { involved }\end{array}$ & $\begin{array}{c}\text { Total } \\
\text { reports* }\end{array}$ & $\begin{array}{c}\text { No. of } \\
\text { children } \\
\text { involved }\end{array}$ \\
\hline $\begin{array}{c}\text { Nov. 1, 1946, to } \\
\text { Feb. 14, 1947 .. }\end{array}$ & 176 & 22 & 123 & 24 \\
$\begin{array}{c}\text { Feb. 14, 1947, to } \\
\text { May 31, 1947 }\end{array}$ & 127 & 21 & 40 & 12 \\
$\begin{array}{c}\text { April and May, } \\
\text { 1947 . . } \\
\text { Loose stools only } \\
\text { during April } \\
\text { and May, 1947 }\end{array}$ & 75 & 19 & 10 & 7 \\
\hline
\end{tabular}

* Total reports $=$ No. of occasions (24-hour period) children were reported as having loose stools and/or vomiting.

During the period November 1, 1946, to February 14,1947 , taking into consideration admissions and discharges, there was a total of thirty-five children on ' $A$ ' and thirty-eight children on ' $B$ ' blocks. For the period February 14 to May 31 the corresponding figures were twenty-nine children on ' $A$ ', and thirty-two on ' $B$,' so that the number of children 'at risk' on the two blocks is therefore comparable.

HAEMOGLOBIN BEFORE AND AFTER TREATMENT. The haemoglobin of each child on ' $A$ ' and ' $B$ ' was estimated at the end of January and again at the beginning of June. There was some improvement in the haemoglobin of the children in ' $B$ ', block after treatment with mepacrine, but as the two groups (' A' and ' B' blocks) were not strictly comparable as regards level of haemoglobin in January it was not possible to assess how much of this improvement could be attributed to the elimination of Giardia lamblia. Unfortunately in a nursery of this type it is not possible to compare treated and control groups over a period longer than a few months as there is constant wastage from children returning home, being adopted, etc.

OTHER EFFECTS ON THE HEALTH OF THE CHILDREN ON 'B.' It was difficult to assess the effect of mepacrine treatment on appetite and muscle tones. Muscle tone was poor in the majority of these 
long-stay children when the investigation began; and in June, when the children were able to get plenty of fresh air and sunshine, the general conditions of both groups ' $A$ ' and ' $B$ ' had improved, but possibly ' $B$ ' showed greater improvement. For the most part the appetites of the children on both ' $A$ ' and ' $B$ ' were good, and there was no obvious change following mepacrine.

TREATMENT OF ' $A$ ' BLOCK WITH MEPACRINE. At the beginning of June all the controls on ' $A$ ' block were given a five-day course of mepacrine. During the subsequent month there was a definite improvement, both as regards incidence of loose stools and rate of weight gain. It was not possible, unfortunately, to continue observation of the individual children on ' $A$ ' and ' $B$ ' after the beginning of July. Many of the original children had already been discharged, and of those remaining some were due for transfer to nursery schools. Further, it had been decided to rearrange the accommodation of the nursery and it was no longer practical to have two comparable groups of long-stay children.

Rebtionship of Giandia infestation to the onset of diarrboea. During the period of survey nineteen children who were negative on admission became infested with Giardia a month or more later. Two of these children were admitted to hospital. Only one appeared ill at the time of admission to hospital; the other, who had had Giardia cysts in the stools for some weeks, had blood in the stools and clinically suggested a case of Sonne dysentery (history of Sonne dysentery twice before), but repeated stool examinations failed to confirm this. In the other cases there appeared to be no relationship between the occurrence of Giardia cysts in the stools and the onset of diarrhoea, and in three of the cases who became infested no loose stools were reported.

After admission to the nursery a record was kept of the number of occasions (twenty-four-hour period) that a child was reported for loose stools. The results obtained for the first five months of 1947 showed that loose stools were about as frequent in the children who remained negative as in those who became positive. The majority of the children in this group were short-stay children, that is, they were at the nursery less than three months.

During the period of investigation eight children over the age of one year at Ladywell Nursery were sufficiently ill with diarrhoea to be admitted to hospital. Two of these had Giardia cysts in their stools and have been mentioned above. Two of the remainder were involved in an outbreak of severe enteritis on the admission block ' $C$,' four cases being admitted to hospital (two of them only ten months old), and there were two deaths. The onset was acute, with diarrhoea, vomiting, and marked prostration, and no outbreak of such severity had been seen amongst children of this age group in the previous twelve months. The cases occurred within a few days of one another, and there appeared to be no evidence that Giardia was in any way connected with this outbreak. No evidence of Giardia infestation was found in the remaining four children in spite of repeated examinations which included examination for flagellates of fresh stools and duodenal fluid. Bacteriological examination failed to find any pathogenic organisms, and administration of sulphasuxidine was without effect. No evidence of parenteral infection was found. Recovery was slow but uneventful, and it was two or three weeks before the children's appetites became normal.

\section{Discussion}

It has been shown that there was a very high incidence of Giardia infestation among long-stay children in residential nurseries, and that there was a higher incidence of loose stools in these children than in children on admission to the nursery. There was, however, no significant difference between the heights, weights, and character of stools of children who had Giardia cysts in their stools on admission to the nursery and those who had not. A follow-up of children during their first few weeks or months of nursery life showed that loose stools were about as frequent in those who remained free of Giardia infestations as in those who became positive. This suggests that factors other than Giardia infestation are of primary importance in explaining the higher incidence of loose stools amongst the nursery children.

It is not possible in this short paper dealing primarily with Giardia lamblia to discuss fully the various other factors leading to diarrhoea and failure to thrive in residential nurseries. Dietetic and psychological disturbances are undoubtedly factors predisposing to diarrhoea during the first few weeks at a nursery, but infections of various kinds, especially upper respiratory, are probably the most important factor. In this nursery, apart from the admission block, there are twenty to twenty-two children on each floor, sharing the same playroom, dining room, bathroom, and potting room. The high incidence of infection during a child's first year at school is well known and in a nursery the child is exposed to the same risks of multiple cross infection at an age when he is less in condition to withstand them. The risks of infection can be overcome to some extent by keeping the children in small groups and allowing them to mix only when out of doors. This method had been adopted on the admission block ' $C$,' but the accommodation on the other blocks was not suitable for the purpose.

Many of the children had loose stools on returning home, but these returned to normal after a period varying from a few days to several weeks without treatment with mepacrine. Furthermore, in no case 
did the parents admit that a child suffered from chronic intermittent diarrhoea as a result of past attendance at this or any other residential nursery. Elimination of Giardia infestation by treatment of a group of long-stay children with mepacrine was followed, however, by a marked improvement in their general health, as shown by the gain in weight and decrease in incidence of loose stools. These apparently contradictory facts together with those previously mentioned can be explained on the assumption that conditions giving rise to a chronic dyspepsia or leading to other forms of intestinal disturbance pave the way for Giardia to assume a pathogenic role. Under these conditions infestation with Giardia leads to the occurrence of intermittent diarrhoea and failure to thrive, although it is probable that a stay of several weeks or months is necessary for this to occur and it thus assumes greater importance in the long-stay child. Whilst such a child remains in the nursery an improvement in his health may be obtained by elimination of the Giardia. If, however, the child returns home it is possible that having thereby removed all the many adverse influences exerting their effect on the nursery child, gradual recovery may occur without removal of the Giardia which assumes a more minor role as the condition of the bowel and the general health of the child improve.

1. The incidence of Giardia infestation on admission to the nursery in children from one to three years was 26.6 per cent. There was no significant difference in the incidence of infestation between the age groups one to two, and two to three years.

2. From a group of eighty-six of these children, thirty had previously attended a day or residential nursery. The incidence of Giardia infestation in these children was $\mathbf{5 0}$ per cent., but the incidence in fifty-six children who had not previously attended any nursery was only $14 \cdot 3$ per cent.

3. The great majority of the long-stay children over one year old at this nursery were infested with Giardia. In a random group of long-stay children the figure reached 79 per cent., and this high figure is in agreement with results obtained at other nurseries. Under the age of one year the incidence of Giardia infestation is low.

4. There was a rapid rate of infestation with Giardia after admission. Of those children who were negative on admission, about two-thirds were infested at the end of two months.

5. The incidence in adults at this nursery was 3.7 per cent. on one examination. Other cases were later found, but the overall incidence was significantly lighter than in nursery children in general.

6. (i) The average child admitted to the nursery was on admission inferior both as regards height and weight to an average child attending the local infant welfare clinic. (ii) The children on admission to the nursery were superior both as regards heights and weights to the children who had been at the nursery for three months or more. (iii) The children who had been at the nursery three months or more were not, when they were admitted to the nursery, inferior to the average child admitted.

7. There was no significant difference in height and weight between children who had Giardia cysts in their stools on admission and those who had not.

8. Loose stools were more frequent in children who had been at the nursery for several weeks than in children just admitted.

9. On admission there was no significant difference between the stools of a Giardia infested child and those of a child not infested.

10. The inference to be drawn from 7 and 9 is that some factors other than Giardia must play a part in accounting for the difference between children on admission to the nursery and those who have been there several months or more. The importance of other factors such as dietetic upset, infections, and psychological disturbances has been mentioned.

11. No significant difference was found between the haemoglobin percentage of the long-stay nursery child and that of children on admission.

12. There was no evidence of any marked inability on the part of the Giardia-infested children to absorb fats.

13. The group of Giardia-infested children treated with mepacrine showed a significantly greater rate of weight gain than the control group of children. The results also suggested that the increase in the height and the haemoglobin percentage of the treated group would have shown a significant improvement over the controls had a longer period of survey been possible. There was a marked decrease in the incidence of loose stools among the treated children.

14. The improvement following mepacrine was a gradual process such as might be expected to occur in a chronically inflamed intestine which would take some time to return to normal.

15. There appeared to be no definite relationship between the occurrence of Giardia infestation and the onset of loose stools. Dietetic upset, infections, especially upper respiratory, and psychological disturbances are probably the important factors predisposing to the onset of diarrhoea after admission to the nursery. 
16. There was no evidence to support the view that severe cases of non-specific enteritis can be attributed to Giardia lamblia. The suddenness of such outbreaks and the rapidity of spread to other children suggests a bacterial or virus cause.

17. The role of Giardia lamblia as a factor in diarrhoea and failure to thrive in residential nurseries has been discussed.

I am indebted to Dr. E. N. Allott for his advice and criticism and for the facilities given to me at the Lewisham Group Laboratory, and to Mr. B. Benjamin of the statistical section of the Public Health Department. I would like to take this opportunity of thanking the staff at Ladywell
Nursery for their co-operation, without which this investigation would not have been possible.

\section{REFERENCES}

Boeck, W. C. (1927). Arch. intern. Med., 39, 134. Galli Valerio (1937). Schweiz. med. Wschr., 67, 1181.

McGrath, J., O'Farrell, P. T., and Boland, S. J. (1940). Irish J. med. Sci., 6th series, p. 802 .

Miller, R. (1926). Arch. Dis. Childh., 1, 93.

Mitchell-Nelson's Textbook of Paediatrics. Edited by W. E. Nelson (1946). W. B. Saunders, Co., Philadelphia and London.

Ormiston, G., Taylor, J., and Wilson, G. S. (1942). Brit. med. J., 2, 151 .

Sudds, M. V. N. (1943). Mon. Bull. Emerg. publ. Hlth. Serv., $2,53$.

Véghelyi, P. V. (1938). Amer. J. Dis. Child., 56, 1231. (1940). Ibid., 59, 793. 